\title{
APLIKASI ASAP CAIR DARI TEMPURUNG KELAPA TERHADAP UMUR SIMPAN SOSIS SAPI
}

\author{
Asep Dedy Sutrisno \\ Hasnelly \\ Hana Nurulan Asri

\begin{abstract}
Program Studi Teknologi Pangan, Fakultas Teknik, Universitas Pasundan, J1. Dr. Setiabudi No. 93, Bandung, 40153, Indonesia

Email: asepdedysutrisno@unpas.ac.id
\end{abstract}

\begin{abstract}
Abstrak
The purpose of this study was to get a result from the use of liquid smoke coconut shell as a preservative in a product of beef sausage that will increase shelf life, as well as to define the type of grade liquid smoke (grade I or grade II) most optimally utilized as a preservative in a product of beef sausage, The research consisted of two stages: a preliminary study to determine the shelf life of beef sausage standards based organoleptic control is 2 days at room temperature, water content of $71.03 \%$. The main intensive search conducted for estimating the shelf life of sausage with the addition of liquid smoke at a temperature of $20^{\circ} \mathrm{C}, 25^{\circ} \mathrm{C}, 30^{\circ} \mathrm{C}$, and $35^{\circ} \mathrm{C}$ with the measured variable are the water content was processed using the Arrhenius method. The results showed that the shelf life is based on water content of beef sausage with the liquid smoke longest grade 1 is at a temperature of $20^{\circ} \mathrm{C}$ for 2.7 days while the second grade is 3.08 days,. Liquid smoke better use grade 2 to the shelf life of sausage.
\end{abstract}

Keywords: Beef Sausage, Liquid Smoke, Shelf Life, Arrhenius Method

\section{Pendahuluan}

Daging segar sebagai bahan makanan relatif lebih variatif dibandingkan dengan daging olahan, tetapi daging segar merupakan media pertumbuhan yang baik untuk mikroorganisme sehingga tergolong bahan pangan yang mudah rusak (perishable food), oleh karena itu proses pengolahan daging segar menjadi daging olahan merupakan proses yang penting. Proses pengolahan daging selain untuk memperpanjang umur simpan daging, penganekargaman bahan pangan, tetapi juga akan meningkatkan nilai gizi serta nilai ekonomis dari produk daging olahan.

Daging diolah menjadi berbagai jenis produk olahan merupakan usaha pengawetan komoditi bahan pangan daging. Selain bertujuan mengawetkan, pengolahan daging juga merupakan usaha penganekaragaman bahan pangan. Daging dapat diolah dengan cara dimasak, digoreng, disate, diasap, atau diolah menjadi produk lain yang lebih menarik seperti corned beef, sosis, dendeng, dan abon sehingga daging dari hasil olahannya merupakan produk-produk makanan yang unik (Soeparno, 2005).

Menurut SNI 01-3820-1995 sosis daging adalah produk makanan yang diperoleh dari campuran daging halus (mengandung daging tidak kurang 75\%) dengan tepung atau pati dengan atau tanpa penambahan bumbu dan bahan tambahan makanan yang diizinkan dan dimasukkan kedalam selubung sosis.

Asap cair merupakan hasil kondensasi dari pirolisis kayu yang mengandung sejumlah besar senyawa yang terbentuk akibat proses pirolisis konstituen kayu seperti selulosa, hemiselulosa dan lignin. Proses pirolisa melibatkan berbagai proses reaksi yaitu dekomposisi, oksidasi, polimerisasi, dan kondensasi. Asap cair memiliki sifat fungsional sebagai antioksidan, antibakteri dan pembentuk warna serta cita rasa yang khas. Sifat-sifat fungsional tersebut berkaitan dengan komponenkomponen yang terdapat didalam asap cair tersebut. Asap cair memiliki kemampuan untuk mengawetkan bahan makanan karena adanya senyawa asam, derivat fenol, dan karbonil (Darmadji, 1995).

Asap cair yang digunakan adalah asap cair yang berasal dari tempurung kelapa. Asap cair tempurung kelapa merupakan hasil kondensasi asap tempurung kelapa melalui proses pirolisis pada suhu sekitar $400^{\circ} \mathrm{C}$. Asap cair mengandung berbagai komponen kimia seperti fenol, aldehid, keton, asam organik, alkohol dan ester (Budijianto dkk, 2008). Berbagai komponen kimia tersebut dapat berperan sebagai antioksidan dan antimikroba serta memberikan efek warna dan citarasa khas asap pada produk pangan (Karseno, 2002).

Keuntungan penggunaan asap cair menurut Maga (1988) dalam Ayudiarti dan Sari (2010) antara lain lebih intensif dalam pemberian citarasa, kontrol hilangnya citarasa lebih mudah, dapat diaplikasikan pada berbagai jenis bahan pangan dengan berbagai cara seperti penyemprotan, pencelupan, atau dicampur langsung dalam makanan.

Hasil uji keamanan asap cair tempurung kelapa menurut Budijanto dkk, (2008) menyatakan asap cair tempurung kelapa dikatagorikan sebagai 
bahan yang tidak toksik dan aman digunakan untuk produk pangan, hasil ini didukung oleh identifikasi pada komponen asap cair tempurung kelapa tidak ditemukan senyawa Policyclyc Aromatic Hydrokarbon (PAH) dan benzo[a]pyren yang bersifat karsinogenik.

Penulis berdasarkan hal diatas tertarik untuk melakukan penelitian tentang asap cair tempurung kelapa sebagai pengawet terhadap produk sosis sapi yang dapat meningkatkan umur simpan, dengan menghitung umur simpan produk sosis sapi metode Arrhenius.

Identifikasi masalah dalam penelitian ini adalah bagaimana pengaruh penggunaan asap cair tempurung kelapa grade I dan grade II pada produk sosis sapi terhadap umur simpannya menggunakan pendekatan

Maksud dari penelitian ini adalah menduga umur simpan dari produk sosis daging sapi dengan penambahan asap cair tempurung kelapa.

Tujuan dari penelitian ini adalah untuk mengetahui berapa lama umur simpan dari sosis daging sapi dengan penambahan asap cair tempurung kelapa.

Hasil penelitian ini diharapkan dapat menjadi bahan informasi bagi konsumen maupun produsen mengenai umur simpan dari sosis yang ditambahkan asap cair tempurung kelapa sebagai pengawetnya. Selain itu juga dapat menjadi suatu alternatif bahan pengawet alami yang dapat digunakan untuk berbagai jenis produk olahan pangan.

Berdasarkan kerangka pemikiran maka diajukan hipotesis bahwa diduga penambahan asap cair tempurung kelapa dapat memperpanjang umur simpan sosis sapi.

\section{Metode Penelitian}

Rancangan perlakuan pada peneletian utama adalah penentuan umur simpan sosis sapi dengan menganalisa respon kimia dan mikrobiologi terhadap pengaruh suhu penyimpanan dan jenis asap cair tempurung kelapa (grade I atau grade II) yang disimpan selama 10 hari pada suhu berbeda-beda yaitu $20^{\circ} \mathrm{C}, \quad 25^{\circ} \mathrm{C}, \quad 30^{\circ} \mathrm{C}$ dan $35^{\circ} \mathrm{C}$ serta dilakukan perhitungan pendugaan umur simpan produk sosis sapi dengan penambahan asap cair berdasarkan pendekatan Arrhenius.

$$
\mathrm{k}=\mathrm{ko} \mathrm{e}^{-\mathrm{E} / \mathrm{RT}} \text { atau } \ln \mathrm{k}=\ln \mathrm{ko}-\mathrm{E} / \mathrm{RT}
$$

Rancangan percobaan yang akan digunakan pada penelitian adalah mencari lama penyimpanan sosis sapi yang sudah dicampur asap cair tempurung kelapa, kemudian menganalisa respon kimia dan mikrobiologi. Setelah itu dilakukan perhitungan dengan menggunakan metode Arrhenius. Berikut contoh tabel hasil analisis kimia dan mikrobiologi pada produk sosis sapi yang sudah dicampur asap cair tempurung kelapa dapat dilihat pada Tabel 1 .
Hasil dari pengamatan pada percobaan ini selanjutnya akan diolah untuk menentukan umur simpan sosis sapi dengan penambahan asap cair grade 1 dan grade 2 menggunakan metode Arrhenius, sehingga dapat diketahui implikasi penggunaan asap cair terhadap umur simpan sosis sapi.

Tabel 1. Tabel Rancangan Hasil Analisis 1

\begin{tabular}{|c|c|c|c|c|c|c|c|}
\hline \multirow{3}{*}{$\begin{array}{l}\text { Suhu } \\
\left({ }^{\circ} \mathrm{C}\right)\end{array}$} & \multirow{3}{*}{$\begin{array}{c}\text { Lama } \\
\text { penyimpanan } \\
\text { (hari) }\end{array}$} & \multicolumn{6}{|c|}{ Hasil Analisis } \\
\hline & & \multicolumn{3}{|c|}{ Kadar Air } & \multicolumn{3}{|c|}{ TPC } \\
\hline & & Kontrol & $\begin{array}{l}\text { Grade } \\
I\end{array}$ & $\begin{array}{l}\text { Grade } \\
\text { II }\end{array}$ & Kontrol & $\begin{array}{l}\text { Grade } \\
I\end{array}$ & $\begin{array}{l}\text { Grade } \\
\text { II }\end{array}$ \\
\hline \multirow{5}{*}{20} & 0 & & & & & & \\
\hline & 2 & & & & & & \\
\hline & 4 & & & & & & \\
\hline & 6 & & & & & & \\
\hline & 8 & & & & & & \\
\hline \multirow{5}{*}{25} & 0 & & & & & & \\
\hline & 2 & & & & & & \\
\hline & 4 & & & & & & \\
\hline & 6 & & & & & & \\
\hline & 8 & & & & & & \\
\hline \multirow{5}{*}{30} & 0 & & & & & & \\
\hline & 2 & & & & & & \\
\hline & 4 & & & & & & \\
\hline & 6 & & & & & & \\
\hline & 8 & & & & & & \\
\hline \multirow{5}{*}{35} & 0 & & & & & & \\
\hline & 2 & & & & & & \\
\hline & 4 & & & & & & \\
\hline & 6 & & & & & & \\
\hline & 8 & & & & & & \\
\hline
\end{tabular}

kemudian di plot kedalam bentuk kurva sehingga akan didapatkan regresi liniernya.

Persamaan regresi linier:

$$
\mathrm{Y}=\mathrm{a}+\mathrm{bx}
$$

dengan demikian, untuk penyimpanan pada suhu $20^{\circ} \mathrm{C}$, $25^{\circ} \mathrm{C}, 30^{\circ} \mathrm{C}$ dan $35^{\circ} \mathrm{C}$ persamaan regresinya adalah:

$$
\begin{array}{ll}
\text { T } 20^{\circ} \mathrm{C} & : y=a+b x(k=b) \\
\text { T } 25^{\circ} \mathrm{C} & : y=a+b x(k=b) \\
\text { T } 30^{\circ} \mathrm{C} & : y=a+b x(k=b) \\
\text { T } 35^{\circ} \mathrm{C} & : y=a+b x(k=b)
\end{array}
$$

Penggunaan regresi linier akan memperoleh koefisien determinasi (r). Setiap nilai b yang diperoleh merupakan konstanta penurunan mutu (k) setiap suhu penyimpanan. Selanjutnya, apabila nilai-nilai $\mathrm{k}$ diterapkan dalam rumus Arrhenius, yaitu:

karena ln ko dan -E/RT merupakan bilangan konstanta, maka persamaan tersebut dapat dituliskan sebagai berikut:

$$
\ln \mathrm{k}=\mathrm{A}+\mathrm{B} .1 / \mathrm{T}
$$


Sehingga apabila setiap nilai $\mathrm{k}$ dan $1 / \mathrm{T}$ diplotkan dalam sebuah grafik, maka akan diperoleh gambar sebagai berikut:

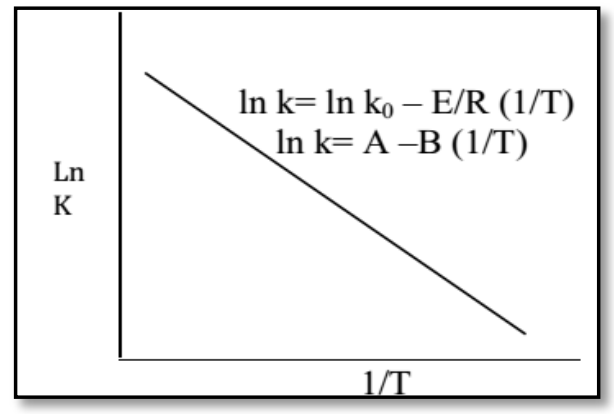

Gambar 1. Grafik hubungan ln k dengan 1/T

Dengan demikian diperoleh besarnya nilai $\mathrm{E}$ dan nilai $\mathrm{k}_{\mathrm{o}}$, yaitu sebagai berikut:

$$
\begin{aligned}
& -\mathrm{E} / \mathrm{R}=\mathrm{B} \\
& \ln \mathrm{k}_{\mathrm{o}}=\mathrm{A}
\end{aligned}
$$

Apabila sudah diperoleh model diatas, dilanjutkan menghitung masa kadaluwarsa (ts) dari percobaan pada beberapa macam suhu, maka selanjutnya dapat dibuat grafik $\ln$ ts terhadap suhu penyimpanan.

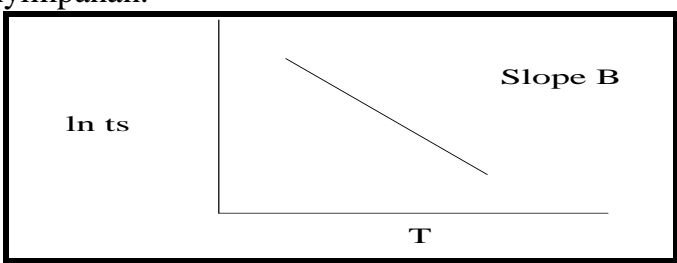

Gambar 2. Grafik hubungan masa kadaluwarsa vs suhu penyimpanan

Dengan regresi linier sederhana akan diperoleh nilai slope terhadap $\mathrm{B}$, selanjutnya masa kadaluwarsa produk tersebut apabila disimpan pada suhu lainnya dapat diduga dengan menggunakan rumus:

$$
\text { ts }=\text { to. } \mathrm{e}^{-\mathrm{BT}}
$$

dimana:

$\mathrm{T}=$ suhu penyimpanan $\left(\mathrm{K} /{ }^{\mathrm{O}} \mathrm{C}\right)$

to = masa kadaluwarsa makanan jika disimpan pada suhu $0\left(\mathrm{~K} /{ }^{\mathrm{O}} \mathrm{C}\right)$

ts = masa kadaluwarsa makanan jika disimpan pada suhu T

$\mathrm{B}=$ slope ( yang besarnya dihitung dari grafik ln vs ts)
Tabel 2. Tabel Rancangan Hasil Analisis 3 (Proksimat)

\begin{tabular}{|l|l|l|l|}
\hline \multirow{2}{*}{ Analisis } & \multicolumn{3}{c|}{ Sosis Sapi } \\
\cline { 2 - 4 } & Kontrol & Grade I & Grade II \\
\hline Protein & & & \\
\hline Lemak & & & \\
\hline Karbohidrat & & & \\
\hline Air Analisis protein yang digunakan \\
\hline \multicolumn{2}{|c|}{ Ang }
\end{tabular}

menggunakan metode Kjeldahl, tujuan dari analisis protein terhadap sosis sapi kontrol, sosis sapi dengan penambahan asap cair grade1, dan sosis sapi dengan penambahan asap cair grade 2 untuk mengetahui pengaruh asap cair terhadap kadar protein dari produk.

Analisis karbohidrat yang digunakan menggunakan metode Luff Schrools, tujuan dari analisis karbohidrat terhadap sosis sapi kontrol, sosis sapi dengan penambahan asap cair grade1, dan sosis sapi dengan penambahan asap cair grade 2 untuk mengetahui pengaruh asap cair terhadap kadar karbohidrat dari produk.

Analisis lemak yang digunakan menggunakan metode soxhlet, tujuan dari analisis lemak terhadap sosis sapi kontrol, sosis sapi dengan penambahan asap cair grade1, dan sosis sapi dengan penambahan asap cair grade 2 untuk mengetahui pengaruh asap cair terhadap kadar lemak dari produk.

Analisis kadar air yang digunakan menggunakan metode gravimetri, tujuan dari analisis kadar air terhadap sosis sapi kontrol, sosis sapi dengan penambahan asap cair grade1, dan sosis sapi dengan penambahan asap cair grade 2 untuk mengetahui pengaruh asap cair terhadap kadar air dari produk.

Analisis pada sosis sapi ini adalah pendugaan umur simpan berdasarkan pendekatan Arrhenius, sehingga dari perhitungan umur simpan tersebut didapat konstanta penurunan mutu (k) dan waktu kadaluwarsa (ts).

Rancangan respon yang akan dilakukan pada penelitian meliputi:

Respon Kimia

Analisis kimia yang dilakukan pada penelitian utama terhadap produk sosis sapi yaitu melakukan analisis kadar air dengan metode Gravimetri,

\section{Hasil Penelitian}

Penelitian pendahuluan dilakukan dengan tujuan mengetahui acuan umur simpan standar sosis sapi tanpa asap cair (kontrol) yang masih layak dikonsumsi sebagai standar umur simpan di penelitian utama. Sosis sapi tanpa asap cair (kontrol) akan disimpan pada suhu ruang dan dilakukan pengujian organoleptik dengan atribut rasa, aroma, warna, dan tekstur. Pengujian organolpetik dilakukan dengan uji hedonik terhadap 30 panelis, dimana nilai tertinggi adalah nilai yang paling disukai oleh panelis. Pengujian hedonik dilakukan sampai panelis menolak, pada saat panelis menolak 
maka dilakukan pengujian kimia (kadar air), dan pengujian TPC. Hasil pengujian kadar air dan TPC akan dijadikan acuan dalam penelitian utama.

Hasil dari pengamatan organoleptik pada sosis sapi menggunakan uji hedonik dengan atribut rasa, aroma, warna, dan tekstur (lendir) didapat hasil bahwa panelis sebanyak 30 orang sudah menolak pada hari ke-2 penyimpanan.

Sosis sapi (kontrol) yang sudah dilakukan pengujian organoleptik (uji hedonik) dapat disimpulkan bahwa panelis menolak produk pada hari ke-2, selanjutnya dilakukan pengujian kadar air dan pengujian TPC sosis sapi yang akan dijadikan acuan standar. Hasil pengujian kadar air dan TPC sosis sapi pada penyimpanan hari ke-2 dapat dilihat pada Tabel 3 . Tabel 1. Data Hasil Analisis Kadar Air dan Total Mikroba (Pendahuluan)

\begin{tabular}{|c|c|}
\hline Pengujian & Sosis Sapi (Kontrol) \\
\hline Kadar air & $71,03 \%$ \\
\hline TPC & $2,04 \times 10^{3} \mathrm{koloni} /$ gram \\
\hline
\end{tabular}

Tabel 1, maka dapat disimpulkan bahwa standar maksimal dari kandungan air pada sosis sapi adalah $71,03 \%$ dan standar maksimal total mikroba pada sosis sapi adalah $2,04 \times 10^{3} \mathrm{koloni} / \mathrm{gram}$. Hasil ini selanjutnya akan digunakan sebagai standar pada penelitian utama.

Penelitian utama bertujuan untuk menduga umur simpan sosis sapi kontrol dan sosis sapi dengan penambahan asap cair grade 1 dan asap cair grade 2 . Analisis yang dilakukan yaitu menghitung jumlah total mikroba, menghitung kadar air, dan uji mutu hedonik. Langkah selanjutnya yaitu mengaplikasikan rumus arrhenius untuk mendapatkan umur simpan produk sosis sapi.

\section{Penentuan Orde Reaksi}

Sampel sosis sapi kontrol disimpan pada empat suhu yaitu $20^{\circ} \mathrm{C}, 25^{\circ} \mathrm{C}, 30^{\circ} \mathrm{C}$, dan $35^{\circ} \mathrm{C}$ kemudian dilakukan pengamatan setiap dua hari sekali sampai hari ke 10. Nilai kadar air yang didapat akan digunakan untuk menentukan orde reaksi. Penentuan orde reaksi didasarkan pada nilai $\mathrm{R}^{2}$. Hasil pengamatan nilai kadar air pada masing-masing ordo dapat dilihat pada Tabel 2.

Tabel 2. Hasil analisis penentuan ordo reaksi

\begin{tabular}{|r|l|l|r|r|}
\hline suhu & $\begin{array}{l}\text { persamaan regresi } \\
\text { ordo 0 }\end{array}$ & $\begin{array}{l}\text { persamaan regresi } \\
\text { ordo } 1\end{array}$ & $R^{2}$ Ordo 0 & $R^{2}$ ordo 1 \\
\hline 20 & $y=0,0209 x+0,6301$ & $y=0,0302 x+4,1467$ & 0,9629 & 0,9651 \\
\hline 25 & $y=0,0217 x+0,646$ & $y=0,0308 x+4,1707$ & 0,9177 & 0,9181 \\
\hline 30 & $y=0,0225 x+0,6497$ & $y=0,0319 x+4,1759$ & 0,8717 & 0,8794 \\
\hline 35 & $y=0,025 x+0,6527$ & $y=0,0352 x+4,1804$ & 0,8269 & 0,8351 \\
\hline
\end{tabular}

Berdasarkan tabel diatas dapat disimpulkan bahwa $\mathrm{R}^{2}$ ordo 1 lebih besar dari $\mathrm{R}^{2}$ ordo 1 , sehingga ordo yang digunakan adalah ordo 1 .

\section{Penentuan Umur Simpan Berdasarkan Kadar Air}

Kadar air adalah persentase kandungan air suatu bahan pangan, kadar air sangat penting dalam menentukan keawetan bahan pangan karena berpengaruh terhadap sifat-sifat fisik, perubahan kimia, enzimatis, dan mikroorganisme (Buckle et al, 2010).

Penentuan kadar air dari sosis sapi dilakukan menggunakan metode gravimetri. Kadar air sosis sapi kontrol, sosis sapi dengan penambahan asap cair grade 1 dan grade 2 yang disimpan pada suhu $20^{\circ} \mathrm{C}, 25^{\circ} \mathrm{C}$, $30^{\circ} \mathrm{C}$, dan $35^{\circ} \mathrm{C}$ kemudian dilakukan pengamatan pada hari ke-0,-2,-4,-6,-8. Hasil analisis kadar air sosis sapi dapat dilihat pada Tabel 5.

Tabel 3. Hasil Analisis Kadar Air Sosis Sapi Selama Penyimpanan

\begin{tabular}{|c|c|c|c|c|c|}
\hline \multirow{2}{*}{$\begin{array}{l}\text { Jenis } \\
\text { Sosis }\end{array}$} & \multirow{2}{*}{ Hari } & \multicolumn{4}{|c|}{ Kadar Air (\%) } \\
\hline & & $\mathrm{T} 20^{\circ} \mathrm{C}$ & T $25^{\circ} \mathrm{C}$ & T $30^{\circ} \mathrm{C}$ & T $35^{\circ} \mathrm{C}$ \\
\hline \multirow{5}{*}{ Kontrol } & 0 & 65,53 & 65,53 & 65,53 & 65,53 \\
\hline & 2 & 66,21 & 70,51 & 71,04 & 72,2 \\
\hline & 4 & 70,01 & 71,25 & 72,52 & 74,35 \\
\hline & 6 & 71,25 & 73,24 & 74,45 & 75,32 \\
\hline & 8 & 73,48 & 75,01 & 75,09 & 76,49 \\
\hline \multirow{5}{*}{ Grade 2} & 0 & 63,54 & 63,54 & 63,54 & 63,54 \\
\hline & 2 & 64,32 & 68,63 & 69,16 & 70,32 \\
\hline & 4 & 68,13 & 69,37 & 70,64 & 72,56 \\
\hline & 6 & 69,37 & 71,14 & 72,57 & 73,44 \\
\hline & 8 & 71,58 & 73,12 & 73,27 & 74,17 \\
\hline \multirow{5}{*}{ Gradel } & 0 & 64,64 & 64,64 & 64,64 & 64,64 \\
\hline & 2 & 65,31 & 69,62 & 70,15 & 71,31 \\
\hline & 4 & 69,12 & 70,36 & 71,63 & 73,46 \\
\hline & 6 & 70,36 & 72,13 & 73,56 & 74,43 \\
\hline & 8 & 72,59 & 74,02 & 74,17 & 75,07 \\
\hline
\end{tabular}

Hasil yang didapat menunjukkan terdapat peningkatan kadar air seiring dengan bertambahnya waktu penyimpanan serta suhu penyimpanan, selanjutnya dari data diatas dengan menggunakan teknik regresi linier dapat diperoleh persamaan regresi dan nilai koefiseien determinasi (r).

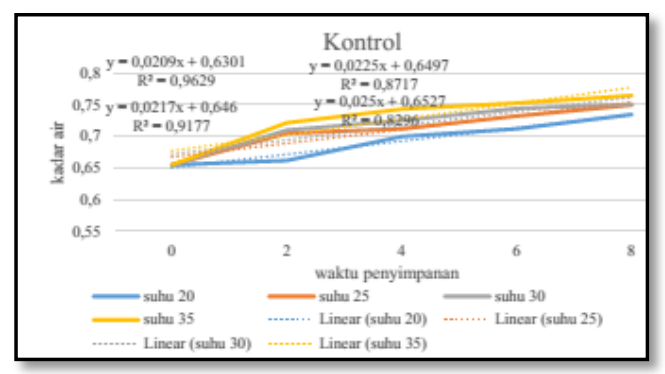

Gambar 3. Kurva Kadar Air Sosis Sapi Kontrol Selama Penyimpanan 


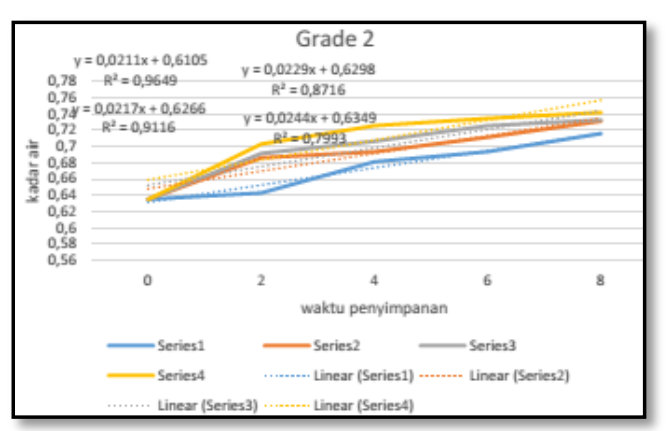

Gambar 4. Kurva Kadar Air Sosis Sapi Dengan Asap Cair Grade 2 Selama Penyimpanan

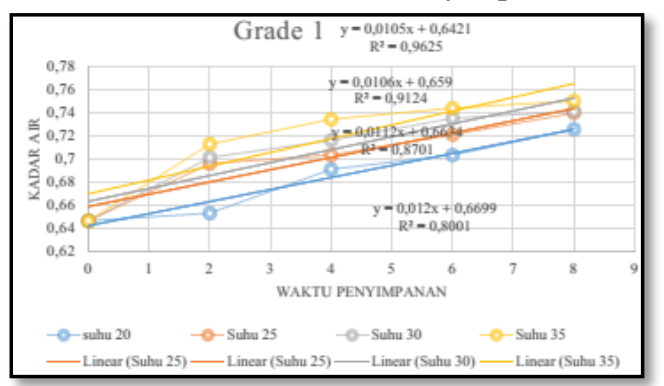

Gambar 5. Kurva Kadar Air Sosis Sapi Dengan Asap

Cair Grade 1 Selama Penyimpanan

Gambar 3, Gambar 4, dan Gambar 5 grafik menunjukkan bahwa nilai b bernilai positif dan setiap kenaikan penyimpanan suhu nilainya juga meningkat. Hal ini menunjukan laju kadar air mengalami kenaikan selama penyimpanan, selain itu perbedaan nilai b pada setiap perbedaan suhu menunjukkan semakin tinggi suhu memiliki derajat kemiringan atau nilai slope tinggi.

Hasil persamaan regresi linier diatas, selanjutnya bisa didapatkan nilai lnk (Tabel 6) yang selanjutnya akan diplot dengan nilai $1 /$ T kedalam suatu grafik. Grafik hubungan lnk dan 1/T dapat dilihat pada Gambar 6, 7, 8.

Koefisien korelasi atau $r$ adalah ukuran hubungan regresi linier antara dua variabel $\mathrm{X}$ dan $\mathrm{Y}$ untuk mengukur sejauh mana titik-titik menggerombol disekitar sebuah garis lurus regresi (Arpah, 2001).

Tabel 4. Hasil perhitungan nilai lnk (kadar air)

\begin{tabular}{|c|c|c|c|c|}
\hline $\begin{array}{c}\text { Jenis } \\
\text { Sosis }\end{array}$ & $\mathrm{T}(\mathrm{K})$ & $1 / \mathrm{T}$ & $\mathrm{k}$ & $\operatorname{lnk}$ \\
\hline \multirow{4}{*}{ Kontrol } & 293 & 0,0034130 & 0,0209 & $-3,8680$ \\
\cline { 2 - 5 } & 298 & 0,0033557 & 0,0217 & $-3,8304$ \\
\cline { 2 - 5 } & 303 & 0,0033003 & 0,0225 & $-3,7942$ \\
\cline { 2 - 5 } & 308 & 0,0032468 & 0,0250 & $-3,6889$ \\
\hline \multirow{4}{*}{$\begin{array}{c}\text { Grade } \\
2\end{array}$} & 293 & 0,0034130 & 0,0211 & $-3,8585$ \\
\cline { 2 - 5 } & 298 & 0,0033557 & 0,0217 & $-3,8304$ \\
\cline { 2 - 5 } & 303 & 0,0033003 & 0,0229 & $-3,7766$ \\
\cline { 2 - 5 } & 308 & 0,0032468 & 0,0244 & $-3,7132$ \\
\hline
\end{tabular}

\begin{tabular}{|c|c|c|c|c|}
\hline \multirow{4}{*}{$\begin{array}{c}\text { Grade } \\
1\end{array}$} & 293 & 0,0034130 & 0,0105 & $-4,5564$ \\
\cline { 2 - 5 } & 298 & 0,0033557 & 0,0106 & $-4,5469$ \\
\cline { 2 - 5 } & 303 & 0,0033003 & 0,0112 & $-4,4918$ \\
\cline { 2 - 5 } & 308 & 0,0032468 & 0,0120 & $-4,4228$ \\
\hline
\end{tabular}

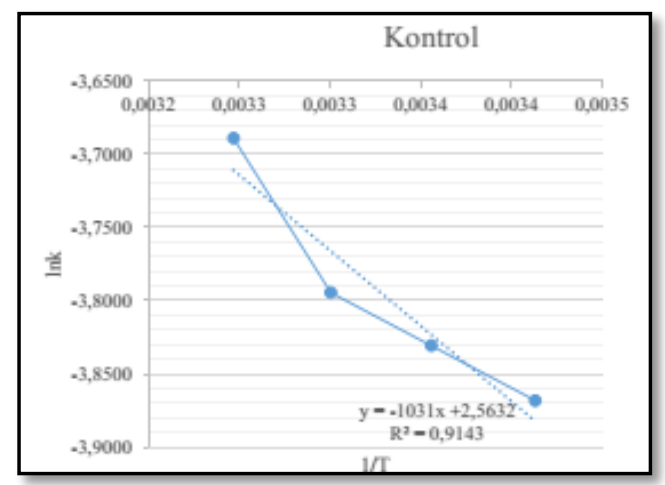

Gambar 6. Grafik Hubungan Antara lnk dengan 1/T(Kadar Air) Pada Sosis Sapi Kontrol

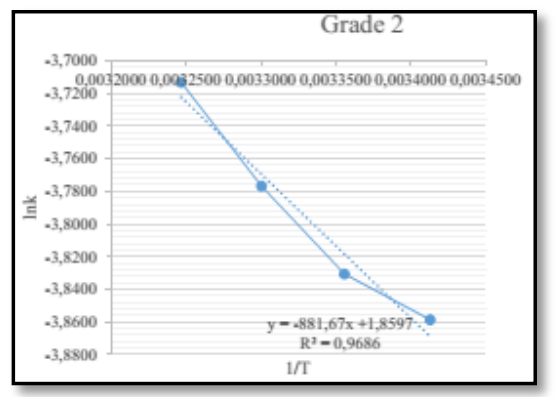

Gambar 7. Grafik Hubungan Antara lnk dengan 1/T (Kadar Air) pada Sosis Sapi dengan Asap Cair Grade 2

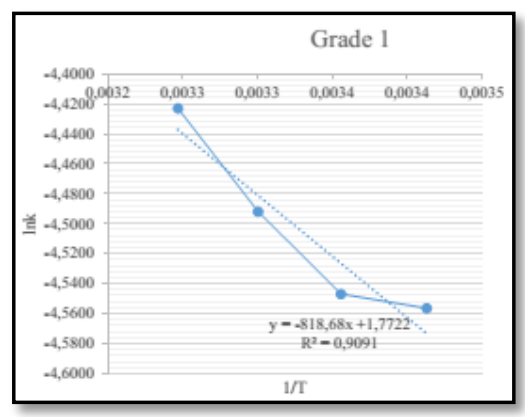

Gambar 8. Grafik Hubungan Antara lnk dengan 1/T (Kadar Air) pada Sosis Sapi dengan Asap Cair Grade 1

Berdasarkan grafik hubungan lnk dan 1/T didapat konstanta penurunan mutu (k) sosis sapi dengan menggunakan rumus berikut:

$$
\mathrm{k}=\mathrm{k}_{0} \cdot \mathrm{e}^{-\mathrm{E} / \mathrm{R} . \mathrm{T}}
$$

Koefesien regresi atau nilai b yang dihasilkan dari masing-masing grafik lnk terhadap $1 / \mathrm{T}$ menunjukkan nilai negatif yang menandakan adanya penurunan lnk kadar air oleh kenaikan suhu 1/T. Nilai $\mathrm{a}, \mathrm{b}$, dan $\mathrm{r}$ selanjutnya digunakan untuk menentukan konstanta laju penurunan mutu. Penurunan mutu pada 
parameter kadar air mengikuti ordo 1 yang kemudian akan didapatkan umur simpan (ts) sosis sapi dengan menggunakan rumus:

$$
\ln \frac{C o / C t}{k}
$$

Tabel 5. Hasil perhitungan nilai $\mathrm{k}$ dan ts (kadar air) sosis sapi

\begin{tabular}{|c|c|c|c|c|c|}
\hline $\begin{array}{l}\text { Jenis } \\
\text { Sosis }\end{array}$ & Suhu ${ }^{\circ} \mathrm{C}$ & $\begin{array}{c}\text { Laju } \\
\text { Penurunan } \\
\text { Mutu k (/hari) }\end{array}$ & $\begin{array}{c}\mathrm{Ea} \\
(\mathrm{Kal} / \mathrm{mol})\end{array}$ & $\begin{array}{c}\text { Umur } \\
\text { simpan(hari) }\end{array}$ & $\begin{array}{l}\text { umur simpan } \\
\quad \text { (jam) }\end{array}$ \\
\hline \multirow{4}{*}{ Kontrol } & 20 & 0,385 & \multirow{4}{*}{2047,56} & 2,5 & 60 \\
\hline & 25 & 0,408 & & 2,4 & 57,6 \\
\hline & 30 & 0,432 & & 2,27 & 54,48 \\
\hline & 35 & 0,456 & & 2,15 & 51,6 \\
\hline \multirow{4}{*}{$\begin{array}{c}\text { Grade } \\
2\end{array}$} & 20 & 0,316 & \multirow{4}{*}{1749,66} & 3,08 & 73,92 \\
\hline & 25 & 0,333 & & 2,92 & 70,08 \\
\hline & 30 & 0,349 & & 2,79 & 66,96 \\
\hline & 35 & 0,366 & & 2,66 & 63,84 \\
\hline \multirow{4}{*}{$\begin{array}{c}\text { Grade } \\
1\end{array}$} & 20 & 0,36 & \multirow{4}{*}{1625,89} & 2,71 & 65,04 \\
\hline & 25 & 0,377 & & 2,59 & 62,16 \\
\hline & 30 & 0,395 & & 2,47 & 59,28 \\
\hline & 35 & 0,412 & & 2,37 & 56,88 \\
\hline
\end{tabular}

Tabel 5 dapat diketahui laju penurunan mutu kadar air masing-masing suhu dan perlakuan berbeda. Konstanta laju penurunan mutu pada suhu $20^{\circ} \mathrm{C}$ lebih kecil dari pada suhu $25^{\circ} \mathrm{C}$, suhu $25^{\circ} \mathrm{C}$ lebih kecil dari pada suhu $30^{\circ} \mathrm{C}$, dan suhu $30^{\circ} \mathrm{C}$ lebih kecil dari pada suhu $35^{\circ} \mathrm{C}$. Hal ini menunjukan bahwa umur simpan sosis sapi akan lebih tahan jika disimpan pada kondisi suhu lebih rendah, semakin tinggi suhu maka konstantan laju penurunan mutu kadar air semakin tinggi mengakibatkan sosis sapi semakin cepat mengalami kerusakan.

Tabel 7 terlihat, bahwa umur simpan sosis sapi kontrol, sosis sapi grade 1, sosis sapi grade 2 mengalami peningkatan umur simpan. Peningkatan umur simpan ini dapat terjadi karena adanya penghambatan pertumbuhan mikroorganisme pada sosis oleh asap cair yang ditambahkan pada sosis sapi. Senyawa dalam asap cair yang berperan menghambat kerusakan produk sosis sapi diantaranya adalah fenol yang berperan sebagai antioksidan dan anti mikroba, kemudian senyawa asam seperti asam asetat, asam propionat, dan asam butirat yang berperan sebagai zat anti bakteri.

Kenaikan kadar air bahan tidak hanya dipengaruhi oleh adanya perbedaan suhu, tetapi adanya perbedaan waktu penyimpanan dan adanya kandungan nutrisi dalam produk dapat menyebabkan mikroba melakukan aktivitasnya seperti metabolisme. Hasil dari metabolisme oleh mikroorganisme dapat menghasilkan air, sehingga kadar air dalam produk meningkat.
Kandungan air dalam bahan pangan mempengaruhi daya tahan bahan pangan terhadap serangan mikroba, yang dinyatakan dalam aw. Aw sangat dipengaruhi oleh kadar air dari bahan pangan (Cahyadi, 2010).

Berdasarkan hasil penelitian aplikasi asap cair dari tempurung kelapa terhadap umur simpan sosis sapi dapat disimpulkan bahwa:

1. Penggunaan asap cair dari tempurung kelapa grade 1 dan grade 2 pada produk sosis sapi berpengaruh terhadap umur simpan produk sosis sapi

2. Hasil penelitian menunjukkan bahwa umur simpan berdasarkan kadar air sosis sapi dengan asap cair grade 1 paling lama yaitu pada suhu $20^{\circ} \mathrm{C}$ sebesar 2,7 hari sedangkan grade 2 sebesar 3,08 hari, umur simpan berdasarkan jumlah total mikroba pada sosis sapi dengan asap cair grade 1 paling lama suhu $20^{\circ} \mathrm{C}$ sebesar 3,09 hari dan grade 2 sebesar 3,12 hari

3. Penggunaan asap cair tempurung kelapa grade 2 lebih dapat memperpanjang umur simpan sosis sapi 2,4 jam lebih lama dibandingkan dengan penggunaan asap cair tempurung kelapa grade 1

\section{DAFTAR PUSTAKA}

1. Apandi, Muchidin. (1993). Teknologi Pengolahan Daging. Universitas Bandung Raya, Bandung.

2. Arpah. (2001). Penentuan Kadarluwarsa Produk Pangan. Program Studi Ilmu Pangan, Institut Pertanian Bogor

3. Ayudiarti, D.L,. Sari,. R.N. (2010). Asap Cair dan Aplikasinya pada Produk Perikanan. Squalen. 5(3), 101-108.

4. Badan Standarisasi Nasional. (1995). Syarat Mutu Sosis Daging. (SNI 01-3820- 1995). Badan Standardisasi Nasional Indonesia, Jakarta.

5. Budijanto, S., dkk. (2008). Identifikasi dan Uji Keamanan Asap Cair Tempurung Kelapa untuk Produk Pangan. Jurnal Pasca Panen. 5(1), 3240.

6. Darmadji, P. (1995). Produksi Asap Cair dan SifatSifat Fungsionalnya. Universitas Gadjah Mada, Yogyakarta.

7. DeMan, J.M. (1997). Kimia Makanan. (Diterjemahkan: K Padmawidata). Penerbit ITB, Bandung.

8. Fardiaz, Srikandi. (1992). Mikrobiologi Pangan. PT Gramedia Pustaka, Jakarta. 